\title{
Preliminary assessment of heavy metals in water, sediment and macrophyte (Lemna minor) collected from Anchar Lake, Kashmir, India
}

\author{
Irfana Showqi ${ }^{1}$. Farooq Ahmad Lone ${ }^{1} \cdot$ Mehrajuddin Naikoo $^{2}$
}

Received: 5 April 2017 / Accepted: 27 April 2018 / Published online: 14 May 2018

(c) The Author(s) 2018

\begin{abstract}
Water samples, sediments and free floating macrophytic plant, Lemna minor specimens were collected from five designated sites in Anchar lake (Srinagar, J\&K, India) to assess its heavy metal (Cu, Cr, Zn, Ni, Cd, Pb) load and changes on seasonal basis. The concentration of heavy metals was determined using atomic absorption spectroscopy. Most of the samples were found within limits of maximum permissible concentrations as recommended by WHO (Guidelines for drinking water quality, pp 491-493, 2006). During all the seasons, highest concentration of all heavy metals $(\mathrm{Cu}, \mathrm{Cr}, \mathrm{Zn}, \mathrm{Ni}, \mathrm{Cd}, \mathrm{Pb})$ was recorded at highly polluted sites of the lake viz. near agricultural fields $\left(\mathrm{S}_{1}\right)$, near settlements $\left(\mathrm{S}_{3}\right)$ and SKIMS $\left(\mathrm{S}_{4}\right)$. These sites received huge agrochemical run-off from the surrounding agricultural fields, solid and liquid wastes from the nearby catchment areas and effluents from Sher-e-Kashmir Institute of Medical Sciences (SKIMS) compared to control site lake centre $\left(\mathrm{S}_{5}\right)$. Furthermore, most of the metals in water and sediment were found with highest concentration during autumn (Viz., Cu-1.5 ppm; Zn-0.38 ppm; Ni-1.89 ppm; Pb-0.84 ppm in water and Cu-26.9 ppm; Zn-13.6 ppm; Pb-4.33 ppm in sediment) and summer (Viz., Cr-0.68 ppm in water and Ni-4.8 ppm; Cd-2.6 ppm; Cr-8.01 ppm in sediment) seasons. Also in Lemna minor plant highest concentration was observed during summer season (Cu-29.09 ppm; Zn-19.11 ppm; Ni-5.7 ppm; Cd-1.34 ppm; Cr-9.18 ppm and Pb-9.77 ppm). From these observations, it was found that the sources of heavy metals in Anchar lake were both natural and anthropogenic ones. This study recommended that continuous monitoring of heavy metals (Viz; $\mathrm{Cu}, \mathrm{Cr}, \mathrm{Zn}, \mathrm{Ni}, \mathrm{Cd}$ and $\mathrm{Pb}$ ) in water, sediment and other aquatic biota of Anchar lake should be directed to protection of ecological status of the lake and its surrounding area.
\end{abstract}

Keywords Heavy metal $\cdot$ Macrophyte $\cdot$ Agro-chemicals $\cdot$ Anchar lake

\section{Introduction}

The urban aquatic ecosystems are strongly influenced by long-term discharge of untreated domestic and industrial wastewaters, storm water run-off, accidental spills and direct solid waste dumping (Sarika and Chandramohankumar 2008). Heavy metal contamination of lake water ecosystems is a worldwide environmental problem. Though some

Irfana Showqi

irfanashowqi@gmail.com

1 Division of Environmental Sciences, Sheri-Kashmir University of Agricultural Sciences and Technology of Kashmir, Shalimar, Srinagar, J\&K 190025, India

2 Division of ARGO, FVSc \& AH, SKUAST-K, Shuhama, Srinagar 190006, India of the heavy metals like $\mathrm{Cu}, \mathrm{Fe}, \mathrm{Mn}, \mathrm{Ni}$ and $\mathrm{Zn}$ are essential as micronutrients for the life processes in animals and plants in very small amounts, other metals like $\mathrm{Cd}, \mathrm{Cr}, \mathrm{Hg}$ and $\mathrm{Pb}$ have no known physiological activities and exhibit extreme toxicity even at trace levels (Nicolau et al. 2006; Kar et al. 2008). In freshwater bodies, there is always presence of some amount of heavy metals derived mostly from the mineralogy and weathering (Samarghandi et al. 2007; Karbassi et al. 2008). However, anthropogenic activities such as mining, long-term disposal of untreated and partially treated effluents containing metals as well as metal chelates, indiscriminate use of heavy metal-containing fertilizers and pesticides in agriculture fields, wet and dry fallout of atmospheric particulate matter, urban run-off and direct solid waste dumping (Kraft et al. 2006 ; Krywult et al. 2008) can accelerate the rate at which these heavy metals are added to the water bodies. Being non-biodegradable these metals 
under some environmental conditions could accumulate and biomagnify through the food chain to toxic levels and eventually result in ecological damage (Walker et al. 2006).

A considerable amount of work has been carried out on different aspects of hydrobiology of the Himalayan lakes (Das et al. 1969; Zutshi et al. 1972; Zutshi et al. 1980; Khulbe 1992 and Jana 1998). The problem of heavy metal pollution is currently increasing in many lakes of Kashmir, India viz. Dal, Nigeen, Anchar etc. The present study was thus designed to assess the heavy metal contamination of the Anchar Lake. The lake being located in the north-west of Srinagar city had become a recipient of urban run-off and surrogate end point for pollutants of domestic and commercial effluents. Due to fast growing settlements around the lake, it is now one of the most polluted lakes of the Kashmir valley. Run-off from agricultural land, pollutants from septic systems, sewers and other human-related activities increase the flux of both inorganic nutrients and organic substances into the Anchar lake. The direct discharge and accidental release of harmful chemical compounds from the SKIMS Institute into the Anchar lake has totally deteriorated the lake quality (ESRO 2007). Pollution of this lake is of grave concern that it is a dwelling place for many birds and is a source of fodder for animals. Therefore, the main objective of the present work was to assess the heavy metal concentration in water, sediment and in Lemna minor, a free floating aquatic plant.

\section{Materials and methods}

\section{Description of study area and sampling sites}

The Anchar lake is situated $14 \mathrm{~km}$ to the north-west of Srinagar city, the summer capital of J\&K state, India. The lake is situated at an altitude of $1583 \mathrm{~m}$ above sea level within the geographical coordinates of $34^{\circ} 20^{\prime}$ to $34^{\circ} 26^{\prime} \mathrm{N}$ latitude and $74^{\circ} 82^{\prime}$ to $74^{\circ} 85^{\prime} \mathrm{E}$ longitudes. It is fed by the cold water river, Sindh, which enters the lake at its northern end, while the southern end receives water from Khushal sar lake. The lake has a number of small outlet channels that drain the lake water into the nearby Shalbough wetland. The lake has shrunken from $19.54 \mathrm{~km}^{2}$ to $5.8 \mathrm{~km}^{2}$ in just 10 -20 years (ESRO 2007). Its encroachment is taking place at a rate of $0.142 \mathrm{~km}^{2}$ year $^{-1}$ (ESRO 2007). The effluents brought in by the Sindh nallah, agriculture wastes and entry of raw sewage from the entire catchment (especially catchment spread over $66 \mathrm{~km}^{2}$ ) has choked the lake. Besides, the lake is receiving effluents containing biomedical substances form the SKIMS, one of the largest hospital in Northern India (ESRO 2007). Such activities have deteriorated the water quality, and now the lake is moving dangerously towards extinction. The sampling sites for the present study were selected depending on the type of land use around the lake (Fig. 1). The identified sites were.

(1) Site-1 (near agricultural fields) Most of the run-off from the agriculture (paddy) fields directly enters into the lake body.

(2) Site-2 (plantation site) The site is surrounded by dense plantation of willow and poplar trees.

(3) Site-3 (near settlements) The washout from the toilets and kitchen wastes from the households are directly discharged into the lake body.

(4) Site-4 (SKIMS Soura) The site is located towards the north-east region of the lake. At this site, the lake receives the toxic effluents and sewage wastes from the drainage system of SKIMS.

(5) Site-5 (lake centre) At this site, the lake has a maximum depth. The site was taken as a control.

\section{Sample collection, preparation and analysis}

Water samples were collected from the five selected sites of the lake at about 10 to $15 \mathrm{~cm}$ below the water surface with the help of a Ruttner sampler. To remove metal contaminants, the sampling plastic bottles were washed with $10 \% \mathrm{HNO}_{3}$ and were rinsed thoroughly with distilled water. Soon after collection, all samples were acidified by adding a few drops of concentrated $\mathrm{HNO}_{3}$. Similarly, Sediment samples from the same selected sites were also collected using Ekman Dredge sampler, and the samples were taken by Grab sampling process. Samples were placed in polyethylene bags. Also plant samples were manually collected from the each designated site. The plant samples were washed with lake water followed by rinsing with distilled water before placed in plastic bags. Later, all samples were packed and labelled carefully (USEPA 1991).

The sediment samples collected from different sites in the lake were oven-dried, grinded in a wooden pestle and mortar and passed through 2-mm sieve. Analysis of different elements was carried out using methodology given by Lindsay and Norvell (1978). About $10 \mathrm{~g}$ of processed sediment sample was shaken for $2 \mathrm{~h}$ with $20 \mathrm{~mL}$ of extractant (0.005 M DTPA, $0.01 \mathrm{M} \mathrm{CaCl}_{2}$ and $0.1 \mathrm{~N}$ TEA buffered at $7.3 \mathrm{pH}$ ) on an electrical shaker and then filtrate was analysed for heavy metals using Atomic Absorption Spectrophotometer (ELEMENTAS AAS4141-Electronics Corporation of India Limited).

Plant samples were digested in a diacidic mixture $\left(9 \mathrm{HNO}_{3}: 3 \mathrm{HClO}_{4}\right)$, i.e. $9 \mathrm{ml}$ of $\mathrm{HNO}_{3}$ and $3 \mathrm{ml}$ of $\mathrm{HClO}_{4}$. To $0.5 \mathrm{~g}$ grounded plant material, $10 \mathrm{~mL}$ of diacidic mixture was added and the contents of the flask were mixed by swirling. The flasks were heated on hot plate in a digestion chamber until the production of red $\mathrm{NO}_{2}$ fumes ceased. The completion of digestion was confirmed when the liquid 


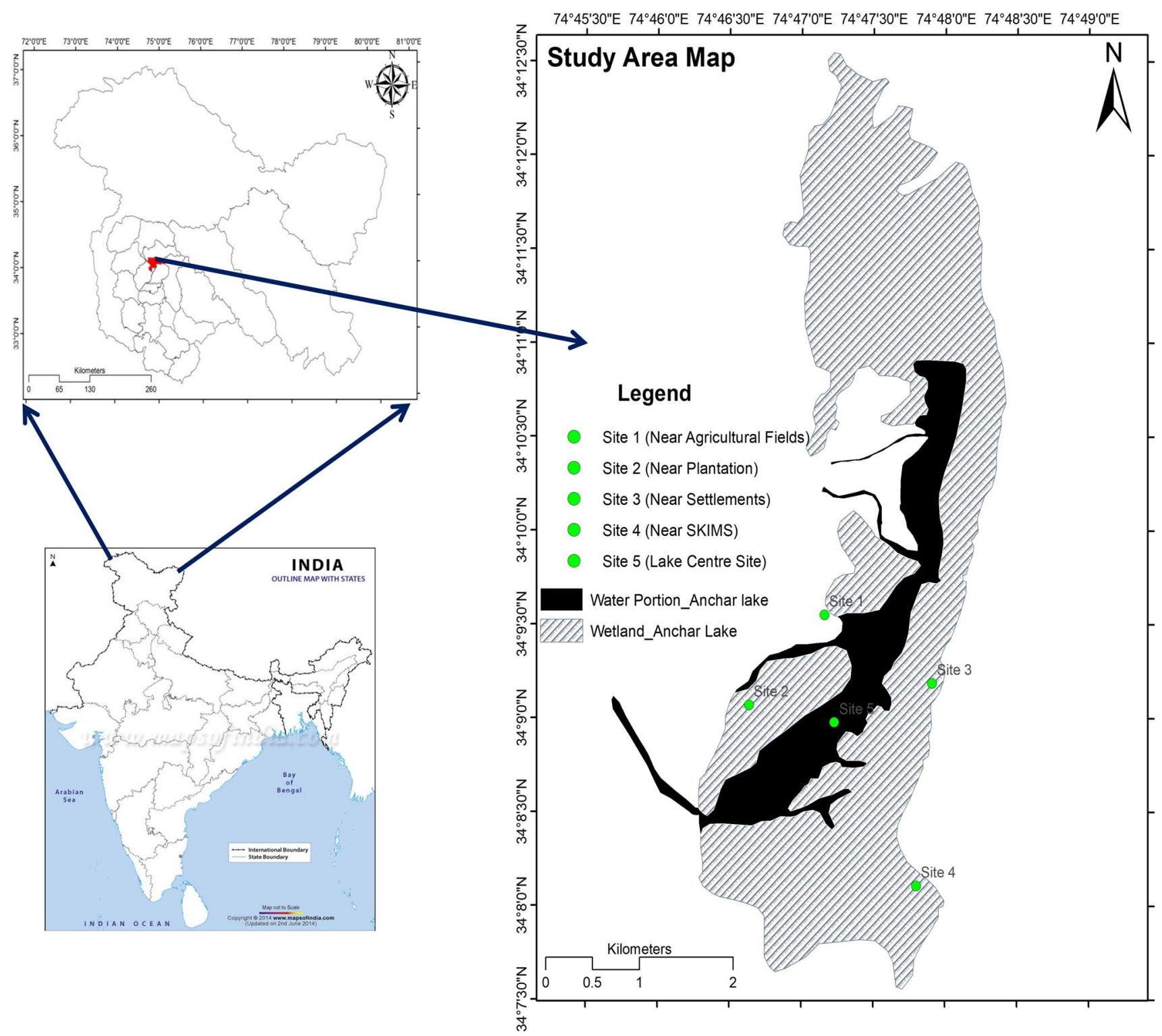

Fig. 1 Study area map and sampling sites

became colourless. After cooling the flasks, the volume of the digested plant material was made $100 \mathrm{~mL}$ by adding Millipore water, and the solution was then filtered through filter paper (Whartmans filter No 42). Aliquots of this solution were then used for the detection of heavy metals, whereas water samples after filtration were directly subjected to heavy metal analysis. This study was carried out during 2014 to 2016.

All the technicalities were ensured to avoid unpredictable changes in characteristics as per standard procedures (APHA 2005). The elements were analysed by direct aspiration of the sample solution into atomic absorption spectrometer after calibration with suitable elemental standards at close intervals. The instrumental setting and operational conditions were done in accordance with the manufacturer's specifications. Average values of four replicates were taken for all detection.

Statistical analysis was carried out using SPSS Version 13 computer package. ANOVA was employed to assess the relationship between heavy metal concentrations and their elemental interaction between sections of the lake.

\section{Results and discussion}

The results of heavy metal concentrations (mean values and standard error /SE) in lake water, sediment and plant Lemna minor are shown in Tables 1, 2 and 3 and Figs. 2, 3 and 4. 
Table 1 Mean value of metal concentration in $\mathrm{mg} \mathrm{L}^{-1}$ of lake water during 2014 to 2016

\begin{tabular}{|c|c|c|c|c|c|c|c|c|c|}
\hline \multirow[t]{2}{*}{ Parameters } & \multirow[t]{2}{*}{ Seasons } & \multirow{2}{*}{$\begin{array}{l}\text { Site 1(Near } \\
\text { agricultural } \\
\text { Fields) }\end{array}$} & \multirow{2}{*}{$\begin{array}{l}\text { Site } 2 \\
\text { (Near plan- } \\
\text { tation) }\end{array}$} & \multirow{2}{*}{$\begin{array}{l}\text { Site } 3 \text { (Near set- } \\
\text { tlements) }\end{array}$} & \multirow{2}{*}{$\begin{array}{l}\text { Site } 4 \text { (Near } \\
\text { SKIMS) }\end{array}$} & \multirow{2}{*}{$\begin{array}{l}\text { Site 5(Lake } \\
\text { centre) }\end{array}$} & \multirow[t]{2}{*}{ Mean } & \multicolumn{2}{|c|}{ C.I (95\%) } \\
\hline & & & & & & & & Lower & Upper \\
\hline \multirow[t]{5}{*}{ Copper $(\mathrm{Cu})$} & Spring & 0.49 & 0.47 & 0.39 & 0.43 & 0.36 & 0.43 & 0.32 & 0.51 \\
\hline & Summer & 0.48 & 0.59 & 0.49 & 0.57 & 0.35 & 0.50 & 0.25 & 0.62 \\
\hline & Autumn & 0.88 & 1.3 & 1.42 & 1.85 & 0.69 & 1.23 & 0.6 & 1.5 \\
\hline & Mean \pm SEM & $0.62 \pm 0.13$ & $0.79 \pm 0.02$ & $0.77 \pm 0.03$ & $0.95 \pm 0.04$ & $0.47 \pm 0.11$ & & & \\
\hline & $\mathrm{CD} \leq 0.05$ & Sites: N.S & & Seasons: N.S & & Site X Seasor & & & \\
\hline \multirow[t]{5}{*}{ Zinc (Zn) } & Spring & 0.12 & 0.08 & 0.07 & 0.05 & 0.08 & 0.08 & 0.03 & 0.11 \\
\hline & Summer & 0.07 & 0.08 & 0.17 & 0.11 & 0.01 & 0.09 & 0.03 & 0.14 \\
\hline & Autumn & 0.21 & 0.04 & 0.39 & 0.43 & 0.08 & 0.23 & 0.01 & 0.38 \\
\hline & Mean \pm SEM & $0.13 \pm 0.04$ & $0.07 \pm 0.03$ & $0.21 \pm 0.09$ & $0.2 \pm 0.11$ & $0.06 \pm 0.02$ & & & \\
\hline & $\mathrm{CD} \leq 0.05$ & Sites: 0.10 & & Seasons: 0.01 & & Site X Seasor & & & \\
\hline \multirow[t]{5}{*}{ Nickel (Ni) } & Spring & 0.56 & 0.06 & 0.07 & 0.88 & 0.07 & 0.33 & -0.09 & 0.65 \\
\hline & Summer & 0.11 & 0.08 & 0.08 & 1.41 & 0.04 & 0.34 & -0.35 & 1.63 \\
\hline & Autumn & 0.11 & 1.57 & 1.41 & 2.2 & 0.33 & 1.12 & 0.01 & 1.89 \\
\hline & Mean \pm SEM & $0.26 \pm 0.15$ & $0.57 \pm 0.05$ & $0.52 \pm 0.04$ & $1.5 \pm 0.03$ & $0.15 \pm 0.09$ & & & \\
\hline & $\mathrm{CD} \leq 0.05$ & Sites: 0.20 & & Seasons: 0.15 & & Site X Seasor & & & \\
\hline \multirow[t]{5}{*}{ Cadmium (Cd) } & Spring & 0.15 & 0.08 & 0.14 & 0.82 & 0.02 & 0.24 & -0.12 & 0.53 \\
\hline & Summer & 0.06 & 0.03 & 0.04 & 0.25 & 0.03 & 0.08 & -0.02 & 0.16 \\
\hline & Autumn & 0.51 & 0.08 & 0.39 & 0.3 & 0.14 & 0.28 & 0.04 & 0.44 \\
\hline & Mean \pm SEM & $0.24 \pm 0.13$ & $0.06 \pm 0.01$ & $0.19 \pm 0.10$ & $0.46 \pm 0.18$ & $0.06 \pm 0.00$ & & & \\
\hline & $\mathrm{CD} \leq 0.05$ & Sites: 0.06 & & Seasons: 0.05 & & Site X Seasor & & & \\
\hline \multirow[t]{5}{*}{ Chromium $(\mathrm{Cr})$} & Spring & 0.43 & 0.32 & 0.34 & 0.46 & 0.26 & 0.36 & 0.2 & 0.45 \\
\hline & Summer & 0.3 & 0.55 & 0.29 & 0.87 & 0.23 & 0.45 & 0.11 & 0.68 \\
\hline & Autumn & 0.33 & 0.62 & 0.45 & 0.68 & 0.27 & 0.47 & 0.21 & 0.63 \\
\hline & Mean \pm SEM & $0.35 \pm 0.03$ & $0.5 \pm 0.09$ & $0.36 \pm 0.04$ & $0.67 \pm 0.11$ & $0.25 \pm 0.01$ & & & \\
\hline & $\mathrm{CD} \leq 0.05$ & Sites: 0.17 & & Seasons: N.S & & Site X Seasor & & & \\
\hline \multirow[t]{5}{*}{ Lead $(\mathrm{Pb})$} & Spring & 0.46 & 0.28 & 0.7 & 0.8 & 0.14 & 0.48 & 0.09 & 0.72 \\
\hline & Summer & 0.52 & 0.33 & 0.67 & 0.6 & 0.11 & 0.45 & 0.12 & 0.65 \\
\hline & Autumn & 0.62 & 0.34 & 0.85 & 0.83 & 0.15 & 0.56 & 0.09 & 0.84 \\
\hline & Mean \pm SEM & $0.53 \pm 0.04$ & $0.32 \pm 0.01$ & $0.74 \pm 0.05$ & $0.74 \pm 0.07$ & $0.13 \pm 0.01$ & & & \\
\hline & $\mathrm{CD} \leq 0.05$ & Sites: 0.22 & & Seasons: N.S & & Site X Seasor & & & \\
\hline
\end{tabular}

$C I$ confidence interval $=95 \%, C D$ coefficient of deviation $=\leq 0.05, S E M$ standard error of mean, $p p m$ parts per million

The results showed that the mean difference of metal concentrations in different media at all study sites was significantly different $(\mathrm{CD}<0.05)$. The presence of toxic metals in the environmental matrices is one of the major concerns of pollution control and environmental agencies in most parts of the world. Their presence in the aquatic ecosystems has far-reaching implications directly to the biota and indirectly to man. Trace metals have been referred to as common pollutants, which are widely distributed in the environment with sources mainly from the weathering of minerals and soils (Lawson 2011). Due to anthropogenic activities, the level of these metals in the environment has increased tremendously during the past decades. The increase in heavy metals in this lake water and sediment might be due to the fact that this region receives huge quantities of sewage, agricultural run-off and toxic effluents from the SKIMS institute (Salim et al. 2013), whereas seasonal variation in metal concentrations at different sites may be attributed to the fluctuations in the amount of agricultural run-off and sewage effluents discharged into the lake (Bahnasawy et al. 2011 and Khan et al. 2012).

The concentration of heavy metals in the sediment was higher than water. Among the samples analysed, zinc was the most abundant heavy metal observed from the different sites of the lake. Water and sediment analyses indicated lower and higher concentrations of zinc content at $\mathrm{S}_{5}$ and $\mathrm{S}_{4}$ sites during summer and autumn season, respectively. The higher concentration of $\mathrm{Zn}$ at site $\mathrm{S}_{4}$ may be due to the entrance of zinc-based chemicals from the nearby medical institute. The aquatic weed Lemna minor on the other side 
Table 2 Mean value of metal concentration in $\mathrm{mg} \mathrm{kg}^{-1}$ of lake sediments during 2014-2016

\begin{tabular}{|c|c|c|c|c|c|c|c|c|c|}
\hline \multirow[t]{2}{*}{ Parameters } & \multirow[t]{2}{*}{ Seasons } & \multirow{2}{*}{$\begin{array}{l}\text { Site } 1 \text { (Near } \\
\text { agriculture } \\
\text { field) }\end{array}$} & \multirow{2}{*}{$\begin{array}{l}\text { Site } 2 \\
\text { (Near plan- } \\
\text { tation) }\end{array}$} & \multirow{2}{*}{$\begin{array}{l}\text { Site } 3 \text { (Near settle- } \\
\text { ment) }\end{array}$} & \multirow{2}{*}{$\begin{array}{l}\text { Site } 4 \text { (Near } \\
\text { SKIMS) }\end{array}$} & \multirow{2}{*}{$\begin{array}{l}\text { Site } 5 \text { (Lake } \\
\text { centre) }\end{array}$} & \multirow[t]{2}{*}{ Mean } & \multicolumn{2}{|c|}{ C.I $(95 \%)$} \\
\hline & & & & & & & & Lower & Upper \\
\hline \multirow[t]{5}{*}{ Copper $(\mathrm{Cu})$} & Spring & 3.80 & 5.30 & 3.20 & 9.90 & 2.80 & 5.00 & 1.9 & 7.5 \\
\hline & Summer & 9.11 & 7.11 & 13.81 & 15.81 & 7.51 & 10.67 & 5.41 & 14.11 \\
\hline & Autumn & 16.92 & 17.72 & 27.01 & 28.7 & 9.91 & 20.05 & 9.7 & 26.9 \\
\hline & Mean & $9.94 \pm 3.8$ & $10.04 \pm 3.8$ & $14.67 \pm 6.8$ & $18.14 \pm 5.5$ & $6.74 \pm 2.1$ & & & \\
\hline & $\mathrm{CD} \leq 0.05$ & Sites: 3.55 & & Seasons: 2.75 & & Site X Season & & & \\
\hline \multirow[t]{5}{*}{ Zinc (Zn) } & Spring & 7.71 & 7.03 & 5.89 & 10.52 & 1.39 & 6.51 & 1.7 & 9.5 \\
\hline & Summer & 6.99 & 6.28 & 7 & 13.85 & 1.38 & 7.10 & 1.21 & 11.01 \\
\hline & Autumn & 10.33 & 7.7 & 12.69 & 13.76 & 1.71 & 9.24 & 2.11 & 13.61 \\
\hline & Mean & $8.34 \pm 1.01$ & $7 \pm 0.41$ & $8.53 \pm 2.1$ & $12.71 \pm 1.09$ & $1.49 \pm 0.10$ & & & \\
\hline & $\mathrm{CD} \leq 0.05$ & Sites: 3.2 & & Seasons: N.S & & Site X Season & & & \\
\hline \multirow[t]{5}{*}{ Nickel (Ni) } & Spring & 2.81 & 2.63 & 3.11 & 5.05 & 2.32 & 3.18 & 2 & 3.1 \\
\hline & Summer & 3.9 & 3.9 & 5.55 & 10.05 & 2.4 & 5.16 & 3.3 & 4.8 \\
\hline & Autumn & 4.31 & 2.91 & 4.32 & 7.12 & 2.07 & 4.15 & 2.01 & 4.3 \\
\hline & Mean & $3.67 \pm 0.4$ & $3.15 \pm 0.3$ & $4.33 \pm 0.7$ & $7.41 \pm 1.4$ & $2.26 \pm 0.09$ & & & \\
\hline & $\mathrm{CD} \leq 0.05$ & Sites: 0.11 & & Seasons: 0.51 & & Site X Season & & & \\
\hline \multirow[t]{5}{*}{ Cadmium (Cd) } & Spring & 1.17 & 0.88 & 1.13 & 1.62 & 0.65 & 1.09 & 1.0 & 1.8 \\
\hline & Summer & 2.65 & 2.42 & 2.5 & 3.55 & 1.25 & 2.47 & 1.0 & 2.6 \\
\hline & Autumn & 1.82 & 1.83 & 1.81 & 1.93 & 0.84 & 1.65 & 1.8 & 2 \\
\hline & Mean & $1.88 \pm 0.4$ & $1.71 \pm 0.4$ & $1.81 \pm 0.3$ & $2.37 \pm 0.5$ & $0.91 \pm 0.17$ & & & \\
\hline & $\mathrm{CD} \leq 0.05$ & Sites: 0.15 & & Seasons: 0.11 & & Site X Season & & & \\
\hline \multirow[t]{5}{*}{ Chromium (Cr) } & Spring & 7.51 & 7.41 & 8.35 & 7.36 & 3.12 & 6.75 & 4.5 & 7.5 \\
\hline & Summer & 8.3 & 8.13 & 7.77 & 8.7 & 6.12 & 7.80 & 6 & 8.01 \\
\hline & Autumn & 8.21 & 5.85 & 5.00 & 3.99 & 3.32 & 5.27 & 3.3 & 5.02 \\
\hline & Mean & $8.01 \pm 0.2$ & $7.13 \pm 0.6$ & $7.04 \pm 1.03$ & $6.68 \pm 1.40$ & $4.19 \pm 0.96$ & & & \\
\hline & $\mathrm{CD} \leq 0.05$ & Sites: 3.57 & & Seasons: N.S & & Site X Season & & & \\
\hline \multirow[t]{5}{*}{ Lead $(\mathrm{Pb})$} & Spring & 2.74 & 0.82 & 2.87 & 2.49 & 0.37 & 1.86 & 0.22 & 2.91 \\
\hline & Summer & 2.5 & 1.9 & 1.7 & 2.4 & 0.4 & 1.78 & 0.5 & 2.6 \\
\hline & Autumn & 3.71 & 2.65 & 3.74 & 4.33 & 1.9 & 3.27 & 1.33 & 4.33 \\
\hline & Mean & $2.98 \pm 0.3$ & $1.79 \pm 0.5$ & $2.77 \pm 0.5$ & $3.07 \pm 0.6$ & $0.89 \pm 0.5$ & & & \\
\hline & $\mathrm{CD} \leq 0.05$ & Sites: 0.46 & & Seasons: 0.35 & & Site X Season & & & \\
\hline
\end{tabular}

$C I$ confidence interval $=95 \%, C D$ coefficient of deviation $=\leq 0.05, S E M$ standard error of mean, $p p m$ parts per million

showed the highest concentration of zinc $\left(17.86 \mathrm{mg} \mathrm{kg}^{-1}\right)$ at site $S_{3}$ during summer season and the lowest concentration at site $\mathrm{S}_{5}$ during autumn season. This may be due to the photosynthetic assimilation or absorption by macrophytes during their growing periods and low levels during autumn season may be due to the death and decay of macrophytes. $\mathrm{Zn}$ concentration in water except at site $\mathrm{S}_{5}$ during summer season was higher than the permissible limit, whereas in sediment it was lower than the permissible limit (Table 4). Intersite comparison showed that heavy metal zinc in all cases recorded the lowest concentration at site $\mathrm{S}_{5}$. This can be attributed to the fact that this site is not under the direct influence of the different pollution sources (Aabid et al. 2013). While, the highest mean value of $\mathrm{Zn}$ in sediments at other sites may be due to high $\mathrm{pH}$ of sediments (Kiflu and
Beyene 2013). Moreover, the highest concentration of $\mathrm{Zn}$ in the macrophytes might be due to the growth of Lemna minor which possesses a unique capacity to absorb large amount of zinc as reported by several researchers (Sridevi et al. 2003).

Copper normally occurs in drinking water from copper pipes, utensils, copper sulphate as a common fungicide. Binning and Baird (2001) reported higher values of $\mathrm{Cu}$ from the aquatic system of industrial areas. In water, low concentrations of $\mathrm{Cu}$ at site $\mathrm{S}_{5}$ may be due to the bioaccumulation by macrophytes as pointed out by Sridevi et al. (2003). The present study also revealed the highest concentration of copper at sites $S_{1}, S_{2}$ and $S_{3}$ which is due to the surface run-off from the nearby agricultural and plantation fields and settlements. Our findings coincided with the observations made by Gray and Becker 
Table 3 Mean value of metal concentration in $\mathrm{mg} \mathrm{kg}^{-1}$ of dry weight of Lemna minor growing in Anchar Lake during 2014 to 2016

\begin{tabular}{|c|c|c|c|c|c|c|c|c|c|}
\hline \multirow[t]{2}{*}{ Parameters } & \multirow[t]{2}{*}{ Seasons } & \multirow{2}{*}{$\begin{array}{l}\text { Site } 1 \text { (Near } \\
\text { agricultural } \\
\text { Fields) }\end{array}$} & \multirow{2}{*}{$\begin{array}{l}\text { Site } 2 \text { (Near } \\
\text { plantation) }\end{array}$} & \multirow{2}{*}{$\begin{array}{l}\text { Site } 3 \text { (Near } \\
\text { settlements) }\end{array}$} & \multirow{2}{*}{$\begin{array}{l}\text { Site } 4 \text { (Near } \\
\text { SKIMS) }\end{array}$} & \multirow{2}{*}{$\begin{array}{l}\text { Site } 5 \text { (Lake } \\
\text { centre) }\end{array}$} & \multirow[t]{2}{*}{ Mean } & \multicolumn{2}{|c|}{ C.I $(95 \%)$} \\
\hline & & & & & & & & Lower & Upper \\
\hline \multirow[t]{5}{*}{ Copper $(\mathrm{Cu})$} & Spring & 26.09 & 24.85 & 21.75 & 25.3 & 20.5 & 23.69 & 16.6 & 27.11 \\
\hline & Summer & 26.68 & 26.18 & 26.24 & 27.09 & 21.32 & 25.50 & 17.92 & 29.09 \\
\hline & Autumn & 20.36 & 20.89 & 20.58 & 24.19 & 19.14 & 21.03 & 15.32 & 23.76 \\
\hline & Mean \pm SEM & $24.38 \pm 2.01$ & $23.97 \pm 1.59$ & $22.86 \pm 1.73$ & $25.53 \pm 0.84$ & $20.32 \pm 0.63$ & & & \\
\hline & $\mathrm{CD} \leq 0.05$ & \multicolumn{2}{|l|}{ Sites: 1.15} & \multicolumn{2}{|l|}{ Seasons: 0.89} & \multicolumn{4}{|c|}{ Site X Seasons: 1.99} \\
\hline \multirow[t]{5}{*}{ Zinc $(\mathrm{Zn})$} & Spring & 12.35 & 12.3 & 13.3 & 15.01 & 8.59 & 12.31 & 7.77 & 14.75 \\
\hline & Summer & 17.03 & 16.17 & 17.86 & 17.65 & 10.45 & 15.83 & 9.63 & 19.11 \\
\hline & Autumn & 11.04 & 9.41 & 10.52 & 13.2 & 6.55 & 10.14 & 6.24 & 12.43 \\
\hline & Mean \pm SEM & $13.47 \pm 1.81$ & $12.63 \pm 1.96$ & $13.89 \pm 2.14$ & $15.29 \pm 1.29$ & $8.53 \pm 1.12$ & & & \\
\hline & $\mathrm{CD} \leq 0.05$ & \multicolumn{2}{|l|}{ Sites: 0.99} & \multicolumn{2}{|l|}{ Seasons: 0.76} & \multicolumn{4}{|c|}{ Site X Seasons: N.S } \\
\hline \multirow[t]{5}{*}{ Nickel (Ni) } & Spring & 2.8 & 3.15 & 3.23 & 4.48 & 2.27 & 3.18 & 1.92 & 3.94 \\
\hline & Summer & 3.53 & 3.78 & 5.55 & 6.13 & 2.35 & 4.26 & 1.87 & 5.7 \\
\hline & Autumn & 2.5 & 2.83 & 4.03 & 4.38 & 1.57 & 3.06 & 1.58 & 4.06 \\
\hline & Mean \pm SEM & $2.94 \pm 0.30$ & $3.25 \pm 0.27$ & $4.27 \pm 0.68$ & $5.00 \pm 0.56$ & $2.06 \pm 0.25$ & & & \\
\hline & $\mathrm{CD} \leq 0.05$ & \multicolumn{2}{|l|}{ Sites: 0.81} & \multicolumn{2}{|l|}{ Seasons: 0.63} & \multicolumn{4}{|c|}{ Site X Seasons: N.S } \\
\hline \multirow[t]{5}{*}{ Cadmium (Cd) } & Spring & 1.13 & 0.52 & 0.69 & 1.13 & 0.44 & 0.78 & 0.25 & 1.09 \\
\hline & Summer & 1.37 & 0.86 & 1.07 & 1.17 & 0.39 & 0.97 & 0.32 & 1.34 \\
\hline & Autumn & 0.86 & 0.62 & 0.64 & 0.86 & 0.24 & 0.64 & 0.22 & 0.89 \\
\hline & Mean \pm SEM & $1.12 \pm 0.15$ & $0.67 \pm 0.10$ & $0.8 \pm 0.14$ & $1.05 \pm 0.09$ & $0.36 \pm 0.06$ & & & \\
\hline & $\mathrm{CD} \leq 0.05$ & \multicolumn{2}{|l|}{ Sites: 0.19} & \multicolumn{2}{|l|}{ Seasons: 0.15} & \multicolumn{4}{|c|}{ Site X Seasons: N.S } \\
\hline \multirow[t]{5}{*}{ Chromium (Cr) } & Spring & 6.7 & 5.94 & 5.8 & 7.02 & 3.09 & 5.71 & 3.61 & 7.08 \\
\hline & Summer & 8.2 & 7.14 & 6.86 & 10.01 & 4.14 & 7.27 & 4.25 & 9.18 \\
\hline & Autumn & 7.1 & 4.24 & 4.67 & 5.2 & 2.72 & 4.78 & 2.46 & 6.22 \\
\hline & Mean \pm SEM & $7.33 \pm 0.44$ & $5.77 \pm 0.84$ & $5.78 \pm 0.63$ & $7.41 \pm 1.40$ & $3.32 \pm 0.43$ & & & \\
\hline & $\mathrm{CD} \leq 0.05$ & \multicolumn{2}{|l|}{ Sites: 0.80} & \multicolumn{2}{|l|}{ Seasons: 0.62} & Site X Season & 1.39 & & \\
\hline Lead $(\mathrm{Pb})$ & Spring & 2.35 & 0.91 & 5.29 & 2.36 & 0.58 & 2.29 & 0.05 & 3.91 \\
\hline & Summer & 6.5 & 5.4 & 5.1 & 12.68 & 2.59 & 6.45 & 1.38 & 9.77 \\
\hline & Autumn & 1.16 & 3.34 & 1.59 & 7.08 & 1.65 & 2.96 & 0.18 & 5.08 \\
\hline & Mean \pm SEM & $3.34 \pm 2.67$ & $3.22 \pm 1.29$ & $3.99 \pm 1.20$ & $7.37 \pm 2.98$ & $1.61 \pm 0.58$ & & & \\
\hline & $\mathrm{CD} \leq 0.05$ & Sites: 2.21 & & Seasons: 1.72 & & Site X Season & N.S & & \\
\hline
\end{tabular}

$C I$ confidence interval $=95 \%, C D$ coefficient of deviation $=\leq 0.05, S E M$ standard error of mean, $p p m$ parts per million

(2002). Kumar et al. (2008) noticed the accumulation of heavy metals in the sediment in the descending order as $\mathrm{Zn}>\mathrm{Cu}>\mathrm{Pb}>\mathrm{Ni}>\mathrm{Co}>\mathrm{Cd}$. In the present observation, the presence of low copper content in the sediment samples was at site $\mathrm{S}_{5}$. Sewage contains large quantities of dissolved organic matter, which promotes the mobility of copper (Khellaf and Zerdaouri 2010). The maximum amount of copper was detected in the sediment samples of $S_{4}, S_{1}, S_{2}$ and $S_{3}$ sites which was mainly by the leaching process from the nearby agriculture fields and settlements. Similar findings were observed by Baligar and Chavadi (2005) in their study. The concentrations of $\mathrm{Cu}$ in water at all sites and in sediment at sites 3 and 4 were higher than the permissible limit (Table 4). In Lemna minor, the highest concentration of $\mathrm{Cu}$ was $27.09 \mathrm{mg} \mathrm{kg}^{-1}$. Jain et al.
(1989) also reported the highest accumulation of heavy metals by Lemna minor and Bacopa from the wastewater.

The chromium content in the sediment varied from $3.12 \mathrm{mg} \mathrm{kg}^{-1}$ at $S_{5}$ to $8.70 \mathrm{mg} \mathrm{kg}^{-1}$ at $S_{4}$ during spring and summer seasons, respectively. Similar results were obtained by Baligar and Chavadi (2005) in the freshwater ecosystems. The low concentration of $\mathrm{Cr}$ was found in water $\left(0.23 \mathrm{mgL}^{-1}\right)$ at site $\mathrm{S}_{5}$ which may be due to its low solubility. Pandey et al. (1995) revealed almost coinciding findings. Enrichment of chromium in particulate matter may be due to the mixing of domestic and industrial waste inputs. Moreover, marshy plants are known to absorb and accumulate more heavy metals from contaminated water and sediment. Lemna minor removes chromium, from the municipal wastewater as shown by (Miretzky et al. 2004). Chromium effects on algae, 

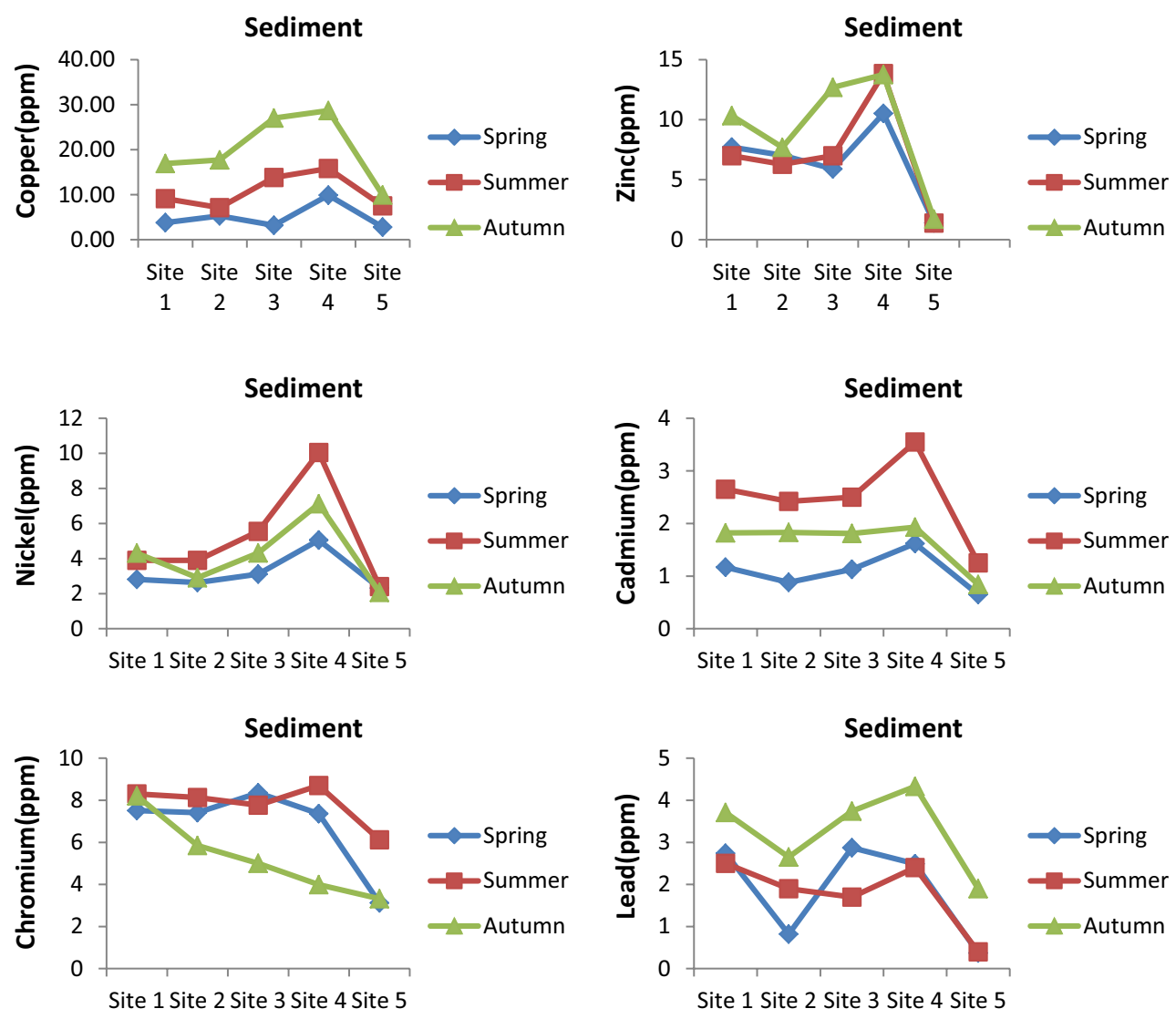

Fig. 2 Variation of heavy metals in sediment over the seasons

duckweed, water hyacinth and water lettuce have also been studied (Satyakala and Jamil 1992). The concentrations of $\mathrm{Cr}$ in water and sediment at all sites were higher than the permissible limit (Table 4).

Lead deposition was maximum $\left(4.33 \mathrm{mg} \mathrm{kg}^{-1}\right)$ at site $\mathrm{S}_{4}$ in the sediment sample. The concentration of lead in the water was highest at site $S_{3}\left(0.85 \mathrm{mgL}^{-1}\right)$. The main source of lead in water may be from contaminated wastes and also from the corrosions of lead batteries/pipes. The lead accumulation in plant tissues showed maximum concentration in the whole plant of aquatic macrophytes. Baldantoni et al. (2004) reported that the shoots of Najas marina show higher concentrations of lead. Lemna minor was observed with higher concentrations of lead $\left(12.68 \mathrm{mg} \mathrm{kg}^{-1}\right)$ during the summer which may be due to photosynthetic efficiency of the plant during their growing period that absorb more and more elements from the growing media. The highest concentration of lead in Lemna minor was also observed by Pillai (2010). Babovic et al. (2010) observed that the leaves of Phragmites communis accumulated less concentrations of lead. Lead is a toxic heavy metal that accumulates in plant and animal tissues through ingestion by food, water and inhalation. Lead sulphide or galena $(\mathrm{PbS})$ is the common form of lead. The main source of lead in the sediment is from lead pipes, mixing of gun powder, waste batteries, etc., into the aquatic systems, which causes lead deposition. The concentrations of $\mathrm{Pb}$ in water and sediment at all sites were less than the permissible limit (Table 4).

The highest amount of cadmium detected in the sediment sample was $1.93 \mathrm{mg} \mathrm{kg}^{-1}$ at site $\mathrm{S}_{4}$ and the lowest amount of $0.65 \mathrm{mg} \mathrm{kg}^{-1}$ was recorded at site $\mathrm{S}_{5}$. The cadmium concentration obtained from the water reached a higher level of $0.82 \mathrm{mgL}^{-1}$ at site $\mathrm{S}_{4}$ against the low level of $0.02 \mathrm{mgL}^{-1}$ at site $\mathrm{S}_{5}$. The order of distribution was decreasing according to the sequence $\mathrm{Cr}>\mathrm{Pb}>\mathrm{Cu}>\mathrm{Zn}>\mathrm{Cd}$. In the case of Lemna minor, the highest and lowest concentrations of cadmium were $1.37 \mathrm{mg} \mathrm{kg}^{-1}$ at site $\mathrm{S}_{1}$ and $0.24 \mathrm{mg} \mathrm{kg}^{-1}$ at site $\mathrm{S}_{5}$. Cadmium is considered as one of the most ecotoxic metal that exhibits adverse effects in various physiological processes of humans, animals, plants and their environment. The cadmium content in the sediment varied from $0.65 \mathrm{mg} \mathrm{kg}^{-1}$ at site $\mathrm{S}_{5}$ during spring season to $1.93 \mathrm{mg} \mathrm{kg}^{-1}$ at site $\mathrm{S}_{4}$ during autumn season which was similar to the results obtained by Baligar and Chavadi 2005 and Kumar et al. (2008) in the freshwater ecosystems. Moreover, low concentration of Cd was observed in the water at site $\mathrm{S}_{5}$ due to less or nil anthropogenic activities. Similar observations were made by Aabid et al. (2013). The concentrations of Cd

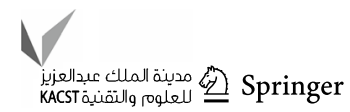


Fig. 3 Variation of heavy metals in water over the seasons

Fig. 4 Variation of heavy metals in Lemna minor over the seasons
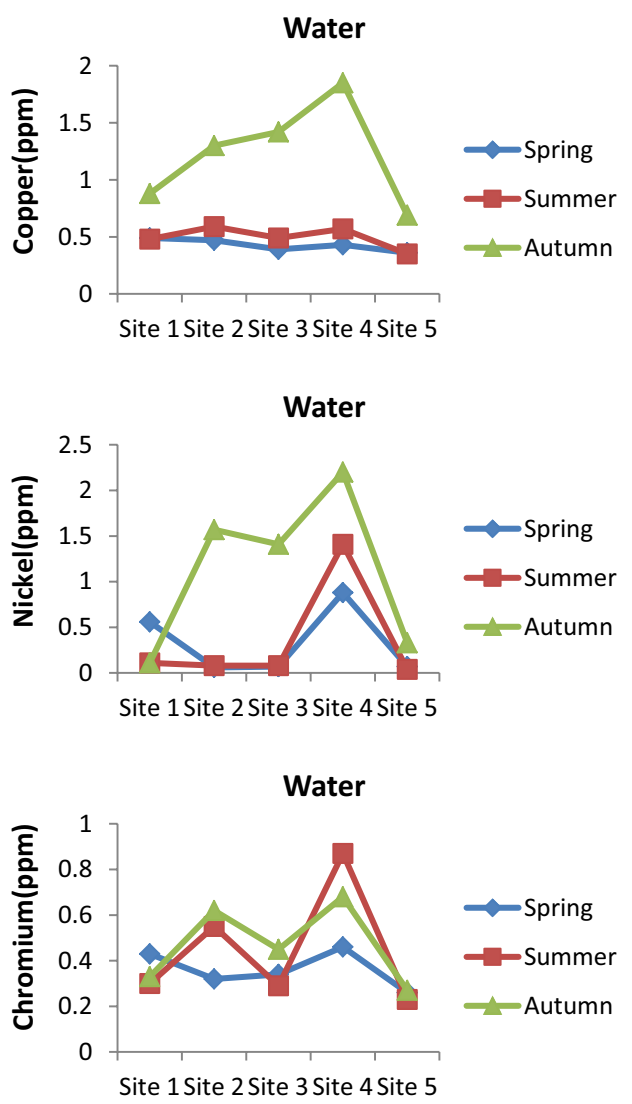

Lemna minor

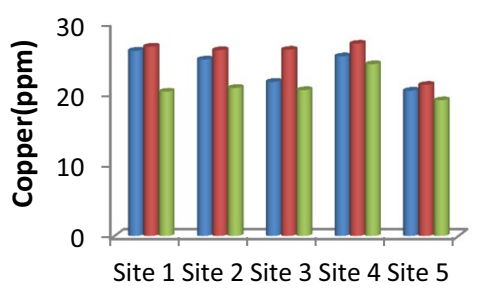

Spring

Summer

Autumn

Lemna minor

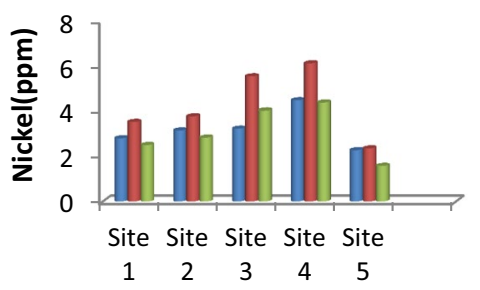

Spring

- Summer

Autumn

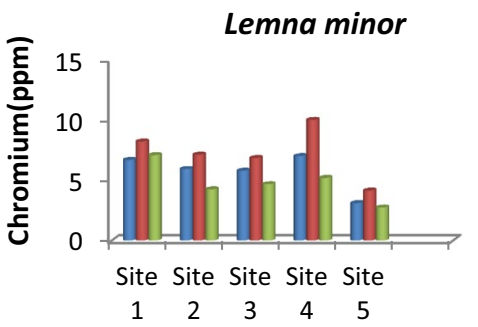

- Spring

- Summer

Autumn $\begin{array}{lllll}1 & 2 & 3 & 4 & 5\end{array}$
Water

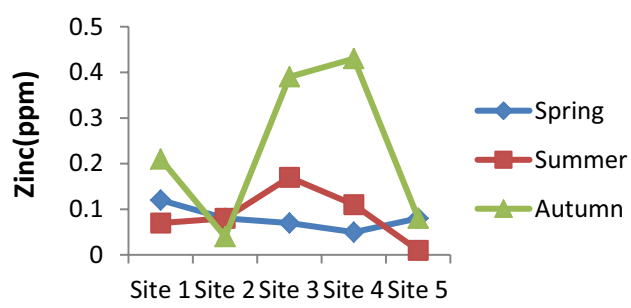

Water

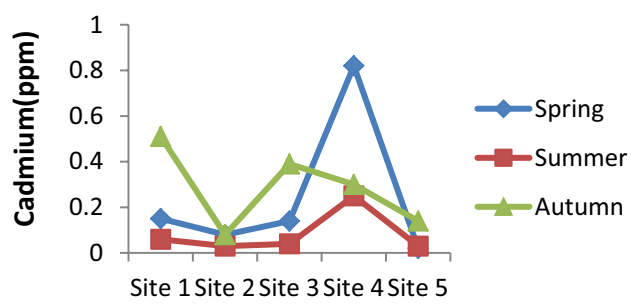

Water

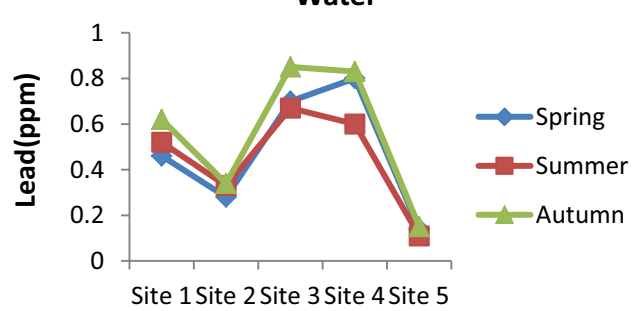

Lemna minor

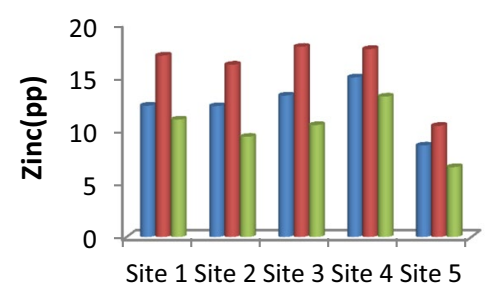

- Spring

- Summer

- Autumn

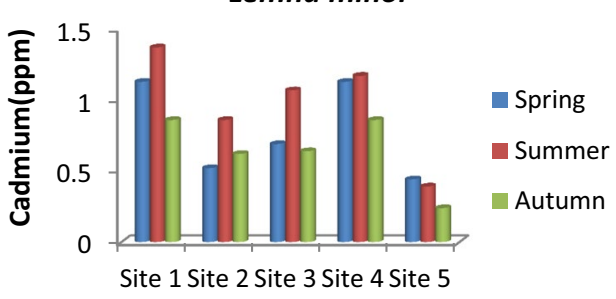

Lemna minor

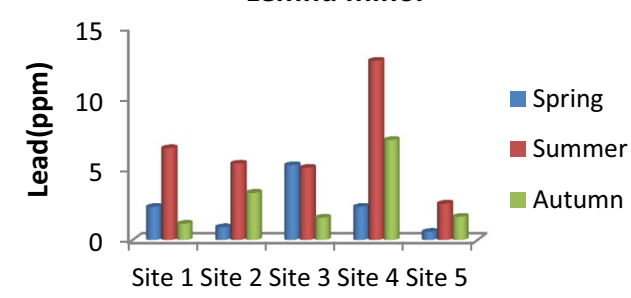


Table 4 Permissible limits of heavy metals in water and sediment

\begin{tabular}{llllllll}
\hline & Cadmium & Zinc & Lead & Copper & Nickel & Chromium & References \\
\hline Water $(\mathrm{mg} / \mathrm{l})$ & 0.01 & 5 & 0.05 & - & - & 0.05 & WHO(2003) \\
& $0.001-0.05$ & - & - & - & - & - & WHO(2006) \\
& 0.003 & 5 & 0.05 & 0.05 & 0.02 & 0.05 & BIS $(2009)$ \\
Sediment $(\mathrm{mg} / \mathrm{kg})$ & 0.05 & - & 0.2 & - & - & - & EC (2005) \\
& $0.03-0.3$ & - & 0.3 & - & - & - & UNEP(1985) \\
\hline
\end{tabular}

in water in spring and autumn were higher than the permissible limit whereas in sediment, concentration was higher than the permissible limit at all sites (Table 4).

In the present study analysis of cadmium accumulation by hydrophytes indicated that the low and high contents were observed by Lemna minor $\left(0.24 \mathrm{mg} \mathrm{kg}^{-1}\right)$ at site $\mathrm{S}_{5}$ and maximum of $1.37 \mathrm{mg} \mathrm{kg}^{-1}$ at site $\mathrm{S}_{1}$.

The observed variability in concentrations of $\mathrm{Pb}$ and Cd may be due to the anthropogenic activities around the Anchar lake. Trace metals are usually present at low concentrations in aquatic environments but their concentrations may be increased due to anthropogenic inputs like municipal wastes, fertilizer and pesticides application and industrial effluents (Muller et al. 2008; Ntakirutimana et al. 2013). The various anthropogenic activities such as vehicular activities, fertilizer and pesticide use, urban farming and domestic waste disposals around these water bodies must have contributed to the pollution status of $\mathrm{Pb}$ and $\mathrm{Cd}$ in the lake. Runoff into this lake could also increase the metal loads. Renier and Sparling (2001) have also reported that run-offs nearby can increase metal concentrations in the water bodies. High variability in the analytical data of metal concentrations in surface waters has been reported to be indicative of an external source (Krishna et al. 2009).

The highest amount of nickel detected in the sediment sample was $10.05 \mathrm{mg} \mathrm{kg}^{-1}$ at site $\mathrm{S}_{4}$, and the lowest amount of $2.07 \mathrm{mg} \mathrm{kg}^{-1}$ was recorded at site $\mathrm{S}_{5}$. The nickel concentration obtained from the water reached higher level of $2.20 \mathrm{mgL}^{-1}$ at site $\mathrm{S}_{4}$ during the autumn season, against the lower concentration of $0.04 \mathrm{mgL}^{-1}$ at site $\mathrm{S}_{5}$ during the summer. In case of Lemna minor, the highest and the lowest concentrations of nickel were $6.13 \mathrm{mg} \mathrm{kg}^{-1}$ at site $\mathrm{S}_{4}$ during summer season and $1.57 \mathrm{mg} \mathrm{kg}^{-1}$ at site $S_{5}$ during autumn season. The fact that there was a significant difference in $\mathrm{Ni}$ concentrations among different sites suggests the presence of an anthropogenic input of $\mathrm{Ni}$. The increase in heavy metals and metal ions might be due to the fact that this lake receives large quantities of sewage, agricultural run-off and effluents from the agricultural fields, settlement effluents, whereas seasonal variation in metal concentration at different sites may be attributed to the fluctuations in the amount of agricultural run-off and sewage effluents discharged into the lake (Bahnasawy et al. 2011; Khan et al. 2012). Generally the highest concentrations of heavy metals in water and sediment were observed during autumn season, and this could be due to death and decay of the macrophytes that release their locked up elements in the growing media. Similarly, the lowest concentrations during summer season might be due to absorption or uptake of elements by the macrophytes during their growth period that sequesters more and more elements from the growing media. Shakeel et al (2013) has also reported the presence of all these heavy metals in the water and macrophyte Phragmites australis in Hokersar wetland of $\mathrm{J} \& \mathrm{~K}$, India. In general, the trend of heavy metals in sediment was $\mathrm{Cu}>\mathrm{Zn}>\mathrm{Ni}>\mathrm{Cr}>\mathrm{Pb}>\mathrm{Cd}$. For plant samples, the trend was $\mathrm{Cu}>\mathrm{Zn}>\mathrm{Pb}>\mathrm{Cr}>\mathrm{Ni}>\mathrm{Cd}$, and in water, the trend was $\mathrm{Ni}>\mathrm{Cu}>\mathrm{Cr}>\mathrm{Pb}>\mathrm{Cd}>\mathrm{Zn}$.

\section{Conclusions}

The spatial and seasonal variations in metal concentrations in water, sediment and Lemna minor were found due to the regular inputs of contaminants from natural and anthropogenic activities around the lake. Although all sampling sites showed the presence of all heavy metals $(\mathrm{Zn}, \mathrm{Cu}, \mathrm{Ni}, \mathrm{Cr}$, $\mathrm{Cd}$ and $\mathrm{Pb}$ ), the concentration of metals at sites $\mathrm{S}_{1}, \mathrm{~S}_{3}$ and $\mathrm{S}_{4}$ was higher than at site $\mathrm{S}_{5}$. The trend followed was site $\mathrm{S}_{4}$ (near SKIMS institute) highly polluted followed by site $\mathrm{S}_{1}$ (near agricultural fields), site $\mathrm{S}_{3}$ (near plantation) and lowest at site $S_{5}$ (lake centre), which could be attributed to enhanced anthropogenic activities at the sites recording the highest concentrations. Metal concentration at most of the sites followed the order as Lemna minor $>$ sediments $>$ water. The water quality of Anchar lake has deteriorated considerably due to illegal encroachment along the banks of the lake, dumping of the sewage and other municipal wastes from different parts of the Srinagar city into the lake. Direct discharge of the human wastes from the nearby settlements into the lake has further aggravated the nature and extent of the pollution. Human encroachments and siltation combined with the other anthropogenic activities reduced the open water quantity within the lake. The elevated levels of heavy metals at different locations of the lake are of utmost concern due to their environmental threats as this lake is the harbour of many water birds, fish and grasses. Therefore, a strategy to control both the point and non-point sources 
of pollution around the lake should be developed for better protection of the lake.

Open Access This article is distributed under the terms of the Creative Commons Attribution 4.0 International License (http://creativeco mmons.org/licenses/by/4.0/), which permits unrestricted use, distribution, and reproduction in any medium, provided you give appropriate credit to the original author(s) and the source, provide a link to the Creative Commons license, and indicate if changes were made.

\section{References}

Aabid HM, Basharat M, Rifat AW, Arshid J, Yousuf AR (2013) Physico-chemical characterization of sediments of river Jhelum around Srinagar, Kashmir, India. Int J Environ Bioenergy 5(1):49-61

APHA (2005) standard methods for examination of water and waste water, 20th edn. American public Health Association, Washington, D.C.

Babovic N, Drazic G, Djordjevic A, Mihailovic N (2010) Heavy and toxic metal accumulation in six macrophythe species from fish pond Ecka, Republic of Serbia. BALWOIS Conference, Ohrid, Republic of Macedonia

Bahnasawy M, Khidr AA, Nadia D (2011) Assessment of heavy metal concentration in the water, plankton and fish of the lake Manzala Egypt. Turk J Zool 35(2):271-280

Baldantoni D, Alfani A, Tommasi PD, Bartoli G, Santo AVD (2004) Assessment of macro and microelement accumulation capability of two aquatic plants. Environ Pollut 130:149-156

Baligar MB, Chavadi VC (2005) Deposition of trace elements in the sediments of Basaveshwar Nagar pond around Gokul industrial area, near Hubli city, Karnataka, India. Ecol Environ Conserv 11(1):81-84

Binning K, Baird D (2001) Survey of heavy metals in the sediments of the Swartkops River Estuary, Port Elizabeth South Africa. Water Soil Air Pollut 27:461-466

BIS (2009) Drinking water specification, second revision IS 10500. ICS No. 13.060.20. pp. 5-10 Bureau of Indian Standards, New Delhi

Das SM, Daftaris S, Singh H, Akhtar S, Choudhary S, Ahmed N (1969) Studies on organic pollution on high altitude lakes of India. Part1: The general ecology of zooplankton of Kashmir lakes, Kounsarnag and Alpather, with correlation of plankton volume, $\mathrm{pH}$ and temperature of Dal lake. Kashmir Sci 1-2:119-132

EC (2005) Commission regulation (EC) No. 78/2005 amending regulation (EC) No. 466/2001 as regards heavy metals. Off J Eur Union, pp 43-45

ESRO-Kashmir Online (2007) Environment Services and Research Organization. Database of Kashmir Environment. file://G:14LIBRARY \LIBRARYafter05(07)\+COUNTRIES $\backslash+I N D I A N K a$ shmir\\#-KASHMIR/LI... 4/8/2007

Gray S, Becker NSC (2002) Contaminant flows in urban residential water systems. Urban Water J 4:331-346

Jain SK, Vasudevan P, Jha NK (1989) Removal of some heavy metals from polluted water by aquatic plants, Studies on duckweed and water velvet. Biol Wastes 28:115-126

Jana BB (1998) State of the art of lake in India, an overview. Archiv fur Hydrobiologie Suppl (Monogr. Stud) 121(1):1-89

Kar D, Sur P, Mandal SK, Saha T, Kole RK (2008) Assessment of heavy metal pollution in surface water. Int J Envir Sci Technol 5(1):119-124
Karbassi AR, Monavari SM, Nabi Bidhendi GR, Nouri J, Nematpour K (2008) Metal pollution assessment of sediment and water in the Shur River. Environ Monit Assess 147(1-3):107-116

Khan MY, Imtiyaz AR, Aijaz AB (2012) Comparative limnological studies of some lakes of Kashmir India. J Appl Pure Biol 27(2):173-179

Khellaf N, Zerdaoui M (2010) Growth, photosynthesis and respiratory response to copper in Lemna Minor, A potential use of duckweed in biomonitoring. Iran J Environ Health Sci Eng 7(2):299-306

Khulbe RD (1992) Studies on water pollution in Nanital and Bhimtal lakes of Kumaun Himalaya. In: 2nd annual progress report, ministry of environment and forests, Govt. of India

Kiflu A, Beyene S (2013) Effects of different land use systems on selected soil properties in south Ethiopia. J Soil Sci Environ Manag 4(5):100-107

Kraft C, Tumpling W, Zachmann DW (2006) The effects of mining in Northern Romania on the heavy metal distribution in sediments of the rivers Szamos and Tisza (Hungary). Acta Hidrochim Hhydrobiol 34:257-264

Krishna AK, Satyanarayanan M, Govil PK (2009) Assessment of heavy metal pollution in water using multivariate statistical techniques in an industrial area, A case study from Patancheru, Medak District, Andhra Pradesh, India. J Hazard Mater 167:366-373

Krywult M, Smykla J, Kinnunen H, Martz F, Sutinen ML, Lakkala K, Turunen M (2008) Influence of solar UV radiation on the nitrogen metabolism in needles of Scots Pine (Pinus Sylvestris L.). Environ Pollut 156(3):1105-1111

Kumar NJI, Soni H, Kumar RN, Bhatti I (2008) Macrophytes in phytoremediation of heavy metal contaminated water and sediments in Pariyej Community Reserve, Gujarat, India. Turk J Fish Aquat Sci 8:193-200

Lawson EO (2011) Physicochemical parameters and heavy metal contents of water from the mangrove swamps of Lagos Lagoon, Lagos Nigeria. Adv Biol Res 5(1):08-21

Lindsay WL, Norvell WA (1978) Development of a DTPA soil test for zinc, iron manganese and copper. Soil Sci Soci Am J 42:421-428

Miretzky P, Saralegui A, Cirelli AF (2004) Aquatic macrophytes potential for the simultaneous removal of heavy metals. Chemosphere 57:997-1005

Muller B, Berg M, Yao ZP, Zhang XF, Wang D, Pfluger A (2008) How polluted is the Yangtze River? Water quality downstream from the three gorges dam. Sci Total Environ 402:232-247

Nicolau R, Galera-Cunha A, Lucas Y (2006) Transfer of nutrients and labile metals from the continent to the sea by a small Mediterranean river. Chemosphere 63(3):469-476

Ntakirutimana T, Du G, Guo JS, Gao X, Huang L (2013) Pollution and potential ecological risk assessment of heavy metals in a lake. Pol J Environ Stud 22(4):1129-1134

Pandey KD, Kashyap AK, Gupta RK (1995) Nutrient status, algal and cyanobacterial flora of six streams of Schirmacher Oasis, Antarctica. Hydrobiol 299:83-91

Pillai P (2010) Accumulation of heavy metals from contaminated wastewater by aquatic plant Lemna minor and their biochemical effects on it. Nat Environ Pollut Technol 9(4):767-774

Renier NK, Sparling DW (2001) Relationships between ambient geochemistry, watershed land-use and trace metal concentrations in aquatic invertebrates living in storm water treatment ponds. Environ Pollut 112:183-192

Shakeel AS, Reshi ZA, Shah MA, Rashid I, Roshan A, Andrabi, MAS (2013) Phytoremediation potential of Phragmites australis in Hokersar wetland, A Ramsar site of Kashmir Himalaya. Int J Phytoremed https://doi.org/10.1080/15226514.2013.821449

Salim AB, Gowhar M, Sayar Y, Rashid AB, Pandit AK (2013) Assessing the impact of anthropogenic activities on spatio-temporal 
variation of water quality in Anchar Lake, Kashmir Himalayas. Int J Environ Sci 3(5):1625-1640

Samarghandi MR, Nouri J, Mesdaghinia AR, Mahvi AH, Nasseri S, Vaezi F (2007) Efficiency removal of phenol, lead and cadmium by means of $\mathrm{UV} / \mathrm{TiO}_{2} / \mathrm{H}_{2} \mathrm{O}_{2}$ processes. Int J Environ Sci Technol 4(1):19-25

Sarika PR, Chandramohankumar N (2008) Geochemistry of heavy metals in the surfacial sediments of Mangroves of the southwest coast of India. Chem Ecol 24:437-447. https://doi.org/10.1080/02757 540802491312

Satyakala G, Jamil K (1992) Chromium induced biochemical changes in Eichhornia crassipes (Mart) solms and Pistia stratiotes. Bullet Environ Contam Toxicol 48:921-928

Sridevi B, Sharief SD, Dawood N, Prabakar K (2003) Bioabsorption of nickel and zinc by water hyacinth-Eichhornia Sp. Ecol Environ Conserv 9(3):361-365

UNEP (1985) Reference methods for marine pollution studies, determination of total $\mathrm{Hg}$ in marine sediments and suspended solids by cold vapour AAS, 26: 1-28

USEPA (1991) Guidelines for developmental toxicity risk assessment. Risk assessment forum U.S Envir Protection Agency II Washington, DC Federal Register. 56(234): 63798-63826
Walker C, Hopkin S, Sibly R, Peakall D (2006) Principles of ecotoxicology. CRC press: Taylor and Francis Group, LLc, London, New York

WHO (2003) Malathion in drinking water, background document for preparation of $\mathrm{WHO}$ guidelines for drinking water quality. (WHO/ $\mathrm{SDE} / \mathrm{WSH} / 03.04 / 103$ )

WHO (2006) Guidelines for drinking water quality. First Addendum to the 3rd edn. Vol 1 Recommendations, pp 491-493

Zutshi DP, Koul V, Vass KK (1972) Limnology of some high altitude Kashmir lakes, India. Verhandlungen des Internationalen Verein Limnologie 18:599-604

Zutshi DP, Shukla BA, Khan MA, Wanganeo A (1980) A comparative limnology of nine lakes of Jammu and Kashmir, Himalaya. Hydrobiol 72:101-112

Publisher's Note Springer Nature remains neutral with regard to jurisdictional claims in published maps and institutional affiliations. 